\title{
The Cotton Mealybug, Phenacoccus Solenopsis Tinsley (Homoptera : Pseudococcidae) as a New Insect on Soybean Plants in Egypt and its Population Dynamic \\ El-Sarand, E. A. \\ Plant Protection Research Institute, Agricultural Research Center, Dokk,Giza,Egypt \\ Email:El_Sarand@yahoo.com
}

ABSTRACT

The cotton mealybug, Phenacoccus solenopsis Tinsley (Homoptera :Pseudococcidae) is an important insect pest worldwide causing economic damage to several crops. The insect was noticed for the first time on soybean, Glycine max L. plants (var. Giza 111) in late August using visual count during season of 2015 at Farm of Sakha Agricultural Research Station, Kafr El-Sheikh, Egypt. The mealybug was collected from the infested soybean plants during season of 2016 at Kafr El-Sheikh Governorate, Egypt and identified as P. solenopsis at Insect Identification Unit, Plant Protection Research Institute, Agricultural Research Center, Egypt. The population density of mealybug started with a few numbers at the end of August during seasons 2015, while in season 2016, the infestation began to appear nearly in mid-August, then it increased gradually till the end of the season. Generally, the population of this insect was significantly higher in the second season than the first one. Both temperature and relative humidity had a negative and insignificant effect on the population in the two seasons with exception of effect of temperature in the second season, as it was negative and highly significant. The combined effect of the two considered weather factors was more pronounced on the population in the second season than in first one. Generally, this study represents the first published record of P. solenopsis on soybean in Egypt. However, the obtained results are very important in integrated soybean management programs to avoid damage of this insect in the future.

Keywords:Population dynamic,soybean, Glycine max L.,mealybug,Phenacoccus solenopsis, visual count,piercing-sucking,weather factors.

\section{INTRODUCTION}

The cotton mealybug, Phenacoccus solenopsis Tinsley (Homoptera: Pseudococcidae) is an important insect pest worldwide with a wide geographical and host range (Williams ,1985; Williams and Granara de Willink, 1992; Miller et al.,2005; Hodgson et al.,2008 and Khuhro et al.,2012). Mealybug,P.solenopsis is a polyphagous and sap sucking insect, as it attacks more than 183 plant species in 52 families (Ben-Dov et al.,2009). The genus phenacoccus is one of the largest genera in the Pseudococcidae, as it currently contains about 180 species (Ben-Dov, 1994). The cotton mealybug has a wide geographical distribution with its origin in Central America (Fuchs et al., 1991) and later spread to several countries such as Ecuador (Ben-Dov, 1994); Chile (Larrian, 2002); Argentina (Granara de Willink, 2003); Brazil (Culik and Gullan, 2005); Pakistan and India (Hodgson et al., 2008); Nigeria (Akintola and Ande, 2008) and China (Wang et al., 2009). In Egypt, P.solenopsis was first recorded on weeds (Abd-Rabou et al., 2010), subsequently as a new insect pest on tomato plants (Ibrahim et al., 2015) and on cotton plants (El-Zahi et al., 2016). Cotton mealybug not only causes direct damage to the host plant by sucking plant sap, but also excretes large quantities of honeydew which encourages the black sooty mold growth and hinders photosynthesis (Arif et al., 2012). Furthermore, the insect is suspected as vector of plant diseases (Culik and Gullan, 2005). P.solenopsis has a high reproductive potential in a wide range of temperature (Prasad et al., 2012) and relative humidity (Hameed et al., 2012). The population of P.solenopsis was significantly and positively correlated with the maximum and minimum temperature, while the correlation between the relative humidity and the population was positive and insignificantly (El-Zahi and Farag, 2017). Thus, the present study was planned to record P.solenopsis for the first time on soybean plants in Egypt and its population dynamic.

\section{MATERIALS AND METHODS}

During growing season of 2015, mealybugs were noticed in a few numbers in late of August on soybean plants (Glycine max L.var. Giza 111) at Farm of Sakha Agricultural Research Station, Kafr El-Sheikh, Egypt. In season of 2016, the infestation with this insect increased on soybean plants. The specimens were collected from various parts of soybean plants on $12^{\text {th }}$ August 2016, and identified at Insect Identification Unit, Plant Protection Research Institute, Agricultural Research Center, Egypt. Mealybug specimens were slide mounted for identification using the method outlined in Williams and Granara de Willink (1992). Identification of the genus was done using the key of the Pseudococcidae family (Hemiptera: Cocccidae) according to Mohammad and Moharum (2012). To study the population dynamics of mealybug, an experimental area of about one Feddan was divided into 4 equal plots at Sakha Agricultural Research Station Farm .The soybean var. Giza 111 was sown in the first week of May during the two study seasons. All plants received the usual recommended agricultural practices without any insecticidal application throughout the two seasons. To determine population of mealybug, 25 soybean branches were selected at random from each plot. The number of adults and nymphs on top $20 \mathrm{~cm}$ of the branch terminal portion were counted directly in the field. The weather factors: temperature and relative humidity were obtained from Meteorological Station of Sakha, Egypt and statistical analysis with SPSS version 16 was used to determine the partial correlation and regression coefficient between the prevailing weather factors and mean population of P.solenopsis.

\section{RESULTS AND DISCUSSION}

The present study represents the first record of mealybug, Phenacoccus solenopsis Tinsley on soybean plant in Egypt during season of 2016 in Kafr El-Sheikh governorate. The insect appeared for the first time in a few numbers on soybean during growing season of 2015. In season of 2016, the infestation started in a few numbers on $12^{\text {th }}$ August and increased gradually till the harvest. Photographs cleared the infestation of P.solenopsis on different parts of soybean plants are shown in Figure (1). Adults and nymphs of cotton mealybug were observed on 
leaves, buds, stems, and pods (Fig. 1: A-D) and feed on the plant sap producing fewer pods of smaller size. The insect also, excretes large quantities of honeydew on the upper surfaces of leaves which encourages the black sooty mold growth and hinders photosynth esis process (Fig.1-B). These results are similar to previously recorded symptoms but on cotton plants (Culik and Gullan, 2005; Osborne, 2005 and Silva, 2012). However, cotton mealybugs in Egypt, was firstly recorded on weeds (Abd-Rabou et al., 2010); on tomato plants (Ibrahim et al. 2015) and on cotton plants (El-Zahi et al., 2016). This study is the first published record of soybean as a host for P.solenopsis in Egypt.

Data presented in Table (1) show th e population density of mealybug on soybean plants and the prevailing weath er factors (temperature and relative humidity) during 2015 and 2016 seasons. In the first season, infestation started on $30^{\text {th }}$ August in a few numbers by 2.00 insects 125 branches of soybean, and then the population increased

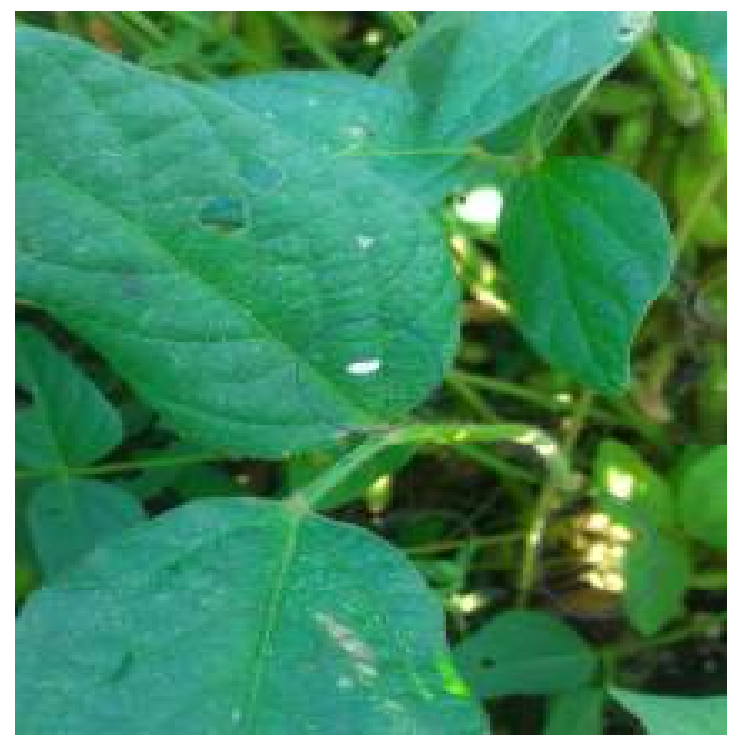

$\mathbf{A}$

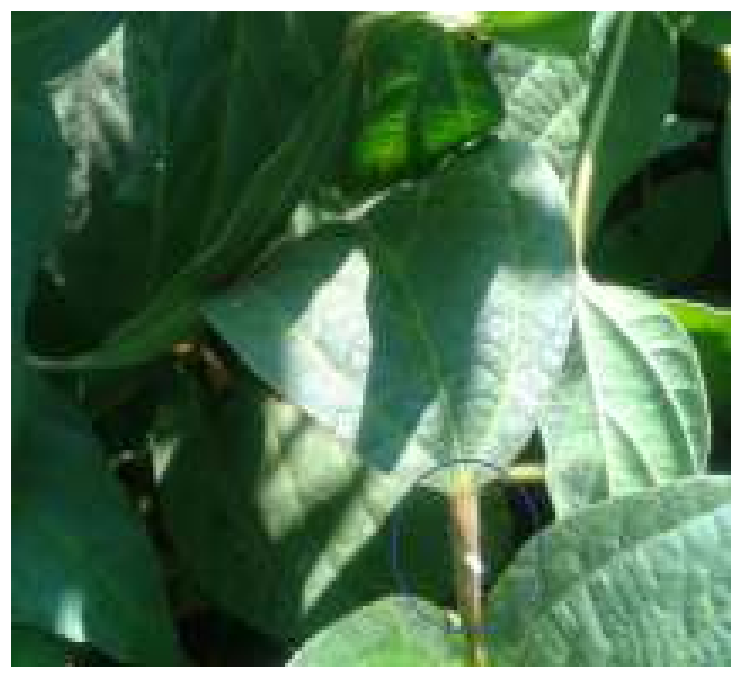

C gradually till the end of season on $28^{\text {th }}$ September with mean numbers of 10.00 insects/25 branches. During season of 2016, the population began to appear on $12^{\text {th }}$ August (1.5 insect $/ 25$ branches ) then, the infestation increased till the harvest on $26^{\text {th }}$ September recording 11.5 insect $/ 25$ branches. Th ese results agreed with findings of El-Zahi and Farag (2017), they reported that the highest population of mealybug on cotton plants was noticed on 11th September.

In general, $t-$ test analysis indicated that the seasonal mean of the insect was significantly higher in season of 2016 than season of 2015, as it was 7.57 and 6.25 insects, respectively. The results in Table (2) cleared that the population of P.solenopsis was negatively and highly significant correlated with temperature in the season of 2016, while temperature in season 2015 and relative humidity in both seasons affected insignificantly and negatively population of mealybug.

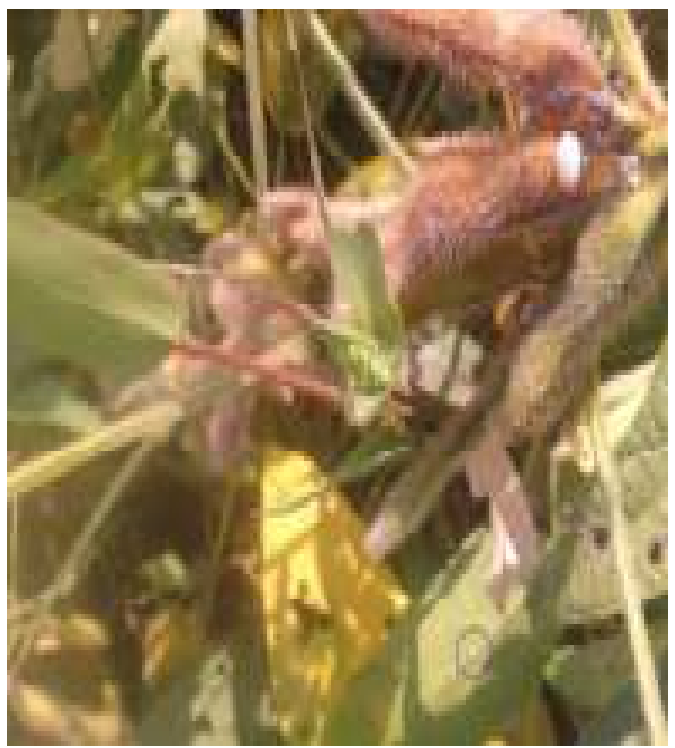

B

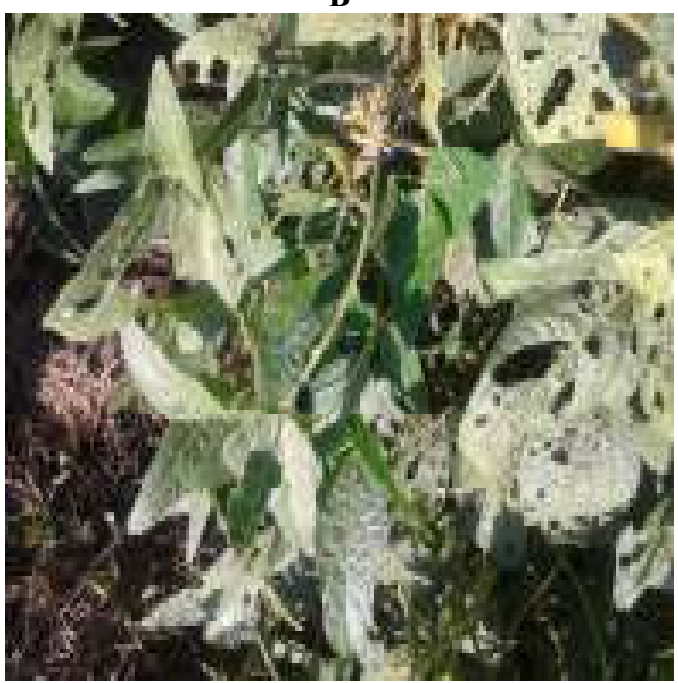

D

Fig. 1. Infestation of Phenacoccus solenopsis Tinsley on different parts of soybean plants. A- nymphs and adults of P.solenopsis on leaves B- excreted honeydew on pods and leaves C - Infestation of buds and leaves D$P$.solenopsis on tillers and leaves 
Table 1. Mean number of Phenacoccus solenopsis Tinsley on soybean plants and the prevailing weath er factors during 2015 and 2016 season at Kafr El-Sheikh governorate, Egypt

\begin{tabular}{|c|c|c|c|c|c|c|c|}
\hline \multicolumn{4}{|c|}{ Season of 2015} & \multicolumn{4}{|c|}{ Season of 2016} \\
\hline Sampling date & $\begin{array}{c}\text { Mean number } / 25 \\
\text { branches }\end{array}$ & $\underset{C^{0}}{\operatorname{Temp}}$ & $\begin{array}{c}\text { RH } \\
\%\end{array}$ & $\begin{array}{c}\text { Sampling } \\
\text { date }\end{array}$ & $\begin{array}{l}\text { Mean number/ } \\
25 \text { branches }\end{array}$ & $\underset{C^{0}}{\text { Temp. }}$ & $\begin{array}{c}\mathbf{R H} \\
\%\end{array}$ \\
\hline Aug.15 & - & - & - & Aug.12 & 1.5 & 29.62 & 73.43 \\
\hline 22 & 0.0 & 30.57 & 65.57 & 19 & 4.75 & 29.54 & 67.07 \\
\hline 30 & 2.00 & 28.89 & 65.63 & 28 & 5.50 & 29.71 & 67.14 \\
\hline Sept.7 & 7.50 & 28.48 & 73.65 & Sept.5 & 8.75 & 28.77 & 69.38 \\
\hline 14 & 8.25 & 29.68 & 67.64 & 12 & 10.25 & 28.49 & 68.38 \\
\hline 21 & 9.73 & 28.68 & 65.93 & 19 & 10.75 & 29.05 & 67.07 \\
\hline 28 & 10.00 & 29.53 & 60.93 & 26 & 11.5 & 27.62 & 66.5 \\
\hline Total & 37.50 & 175.83 & 399.39 & Total & 53.00 & 202.8 & 448.97 \\
\hline Grand mean+SE & $6.25+$ & 29.31 & $66.56 \pm$ & Grand & $7.57 \pm$ & $28.98 \pm$ & $68.42 \pm$ \\
\hline & $0.1 \overline{3}$ & +0.78 & $4.13^{-}$ & mean $+\mathrm{SE}$ & 3.72 & $0.74^{-}$ & 2.41 \\
\hline
\end{tabular}

Table 2. Statistical parameters for mealybug, Phenacoccus solenopsies Tinsley population in relation to certain weather factors on soybean branches during 2015 and 2016 seasons

\begin{tabular}{lccccc}
\hline \multirow{2}{*}{ Season } & \multicolumn{4}{c}{ Temperature. } & \multicolumn{2}{c}{ RH \% } & EV\% \\
\cline { 2 - 6 } & $\mathbf{r}$ & $\mathbf{b}$ & $\mathbf{r}$ & $\mathbf{b}$ & \\
\hline 2015 & -0.54 & -3.27 & -0.29 & -0.30 & $29.12 \%$ \\
2016 & $-0.92 * *$ & -3.31 & -0.66 & -0.63 & $80.23 \%$ \\
\hline (r) = correlation coefficient & $\mathbf{( b ) =}$ regressions coefficient \\
$* *$ High significantly EV=explained variance $\mathbf{R H}=$ relative humidity \\
In season of 2015 & $\mathbf{t}$-tabulated at & $\mathbf{5 \%}=\mathbf{0 . 7 6}$ & $\mathbf{1 \%}=\mathbf{0 . 8 7}$ \\
In season of $\mathbf{2 0 1 6}$ & $\mathbf{t}$-tabulated at & $\mathbf{5 \%}=\mathbf{0 . 7 1}$ & $\mathbf{1 \%}=\mathbf{0 . 8 4}$
\end{tabular}

Based on the regression coefficient, it revealed that decrease of temperature by $1 \mathrm{C}^{\mathrm{O}}$ increased population of P.solenopsis by 3.27 and 3.31 insects per 25 branches in season of 2015 and 2016, respectively, while increase of relative humidity by $1 \%$ decreased population of mealybug by 0.29 and 0.63 insects per 25 branches in 2015 and 2016 season ,respectively. Th ese results agreed with Prasad et al., 2012, as they showed that the development duration of $P$. solenopsis decreased as temperature increased from 18 to $32 \mathrm{C}^{\mathrm{o}}$. In contrast, Hamead et al., (2014) and El-Zahi and Farag (2017) showed that relative humidity had positive effect on the population of P.solenopsis. The combined effect of temperature and relative humidly was responsible for changes in the population density of $P$. solenopsis by 29.12 and $80.23 \%$ during 2015 and 2016, respectively. This means that there are other unconsidered factors affecting on the population. This may be due to the differences in prevailing weather factors or/and its natural enemies.

Finally, it can be concluded that the cotton mealybug, $P$. solenopsis was noticed for the first time on soybean in Egypt and its population changed from season to oth er. Thus, the obtained results are of most importance in the integrated soybean management programs to avoid the spread and potential risk of this insect.

\section{REFERENCES}

Abd-Rabou,S.; J.F. Germain and T. Malausa (2010). Phenacoccus parvus Morrison and P. solenopsis Tinsley, two new scale insects in Egypt (Hemiptera: Pseudococcidae). Bulletin Societie Entomogique France, 115(4):509-510
Akintola, A.J. and A.T. Ande (2008). First record of Phenacoccus solenopsis Tinsley (Hemiptera: Pseudococcidae) on Hibiscus, Rosa sinensis in Nigeria. Agricultural Journal, 3(1):1-3

Arif, M.I.; M. Rafiq and A. Ghaffar (2009). Host plants of cotton mealybug (Phenacccus solenopsis Tinsley): a new menace to cotton agroecosystem of Punjab, Pakistan. International Journal of Agricultural and Biology, 11(2):163-167

Arif, M.I.; M. Rafiq; S.Wazir; N. Mehmood and A. Ghaffar(2012). Studies on cotton mealbug, Phenacoccus solenopsis Tinsley (Pseudococcidae: Homoptera), and its natural enemies in Punjab, Pakistan. Int.J. Agric. Biol.,( 14):557-562

Ben-Dov Y. A. (1994). Systematic Catalogue of the mealybug of the world (Insecta:Homoptera Coccoidea: Pseudococcidae and Putoidae). Intercept Ltd, Paris, France, 686 pp.

Ben-Dov, Y.A.; D.R. Miller and G.A.P. Gibson (2009). ScaleNet: A Searchable Information System on Scale insects. Available on-line at http://www. sel.barc.usda.govscalenet/scalent.htm

CuliK, M.P. and P.J. Gullan (2005). A new pest of tomato and other records of mealybugs (Hemiptera: Pseudococcidae) from Espirito Santo, Brazil. Zootaxa, 964:1-8

El-Zahi,S.E. and A.I. Farag (2017). Population dynamic of Phenacoccus solenopsis Tinsley on cotton plants and its susceptibility to some insecticides in relation to the exposure method .Alexandria Science Exchange Journal, 38(2)231-237

El-Zahi,S.E.; S.A. Aref and S.K.M. Korish (2016). The cotton mealybug ,Phenacoccus solenopsis Tinsly (Hemiptera :Pseudoccidae) as anew menace to cotton in Egypt and its chemical control. Journal of Plant Protection Research, 56(2):111-115

Fuchs,T.W.; J.W. Stewart.; R. Minzenmayer and M. Rose (1991). First record of Phenacoccus solenopsis Tinsley in cultivated cotton in the United States. South western Entomol., 16(3): 215-221

Granara de Willink, M.C. (2003). Nuevas citas y huespedes de Phenacoccusparala Argentina (Hemiptera :Pseudococcidae). (New records and quests of the Argentina Phenacoccuspara (Hemiptera: Pseudococcidae)). Revista de la Sociedad Entomologica Argentina, 62 (3/ 4):80-82. (in Spanish with English summary) 
Hameed,A.; M.A.Aziz and G.M.Aheer(2012). Impact of ecological conditions on biology of cotton mealybug, Phenacoccus solenopsis Tinsley (Hemiptera :Pseudococcidae) in laboratory. Pakistan Journal of Zoology, 44(3):685-690

Hameed,A.; M.S. Shahzad; A.Mehmood, S.Ahmad and N.Islam(2014). Forecasting and modeling of sucking insect complex of cotton under agroecosystem of Multan-Ppunjab,Pakistan. Pakistan Journal of Agricultural Sciences, 51(4):99-103

Hodgson, C.J.; G. Abbas;M.J. Arif; S.Saeed and H.Karar (2008). Phenacoccus solenopsis Tinsley (Steronorrhyncha: Coccoidea: Pseudococcidae), a new invasive species attacking cotton in Pakistan and India, with a discussion on seasonal morphological variation. Zootaxa, 1913:1-35

Ibrahim,S.S.; F.A. Moharumand and N.M. Abd El-Ghany (2015). The cotton mealybug Phenacoccus solenopsis Tinsley (Hemiptera :Pseudococcidae) as a new insect pest on tomato plants in Egypt. Journal of Plant Protection Research, 55(1):48-51

Khuhro,S.N.;A.M. Kalroo and R. Mahmood (2012). Present status of mealybug, Phenacoccus solenopsis Tinsley on cotton and oth er plants in Sindh (Pakistan).p.268-271.In:Book of Papers. World cotton Research Conferece-5, Mumbia, 07-11 November 2011, 580pp.https:// www.icac. org/meetings/ wcrc/5/Proceeding.pd

Larrian,S.P.(2002). Insect and mile pest incidence on sweet pepinos (Solanum muricatum Ati) cultivated in the IV Region Chile. Agricultura Tecnic, 62(1):1526

Miller, D.R.; G.L. Miller; G.S. Hodges and J.A. Davidson (2005). Introduced scale insect (Hemiptera: Coccodea) of the United States and their impact on U.S.agriculture. Proceedings of the Entomological Society of Washington, 107 (1):123-158
Mohammad,Z.K. and F.A. Moharum (2012). Key the genus of family Pseudococcidae (Hemiptera: Coccoidea) in Egypt, Egyptian Academic Journal of Biological Science, 5(3):1-5

Osborne,L.S.(2005). Mealybug. htt://www.merc.ifas.ufl. edu/ Iso/ Mealybugs. htm. (Accessed; March 1, 2014).

Prasad, Y.G.; M.Prabhakar; G.Sreedevi, G.R.Rao and B.Venkateswarlu (2012). Effect of temperature on development, survival and reproducing of the mealybug, Phenacoccus solenopsis Tinsley (Hemiptera :Pseudococcidae) on cotton. Crop Protection, 3(9):81-88.

Silva, C.A.D. (2012). Occurrence of new species of mealybug on cotton fields in the States of Bahia and Paraiba, Barazil. Bragantia, Campinas, 71(4):467470

SPSS (2006). Statistical Package 1-56827-390-8 SPSS 15.0 Command Syntax Reference, SPSS Inc., Chicago.

Wang,Y.P.; S.A.Wu and R.Z.Zhang (2009). Pest risk analysis of a new invasive pest, Phenaccocus solenapsis, to China. Chinese Bull. Entomol., 46(1):101-106

Williams, D.J. and M.C.Granara de Willink (1992). Mealybug of Central and South America. CAB International, London, England, $635 \mathrm{pp}$.

Williams,D.J.(1985). Australian Mealybugs. British Museum (Natural History), London, England, 431pp.

\section{بق القطن الدقيقى Phenacoccus solenopsis Tinsley (Homoptera :Pseudococcidae) حشرة جديدة على نباتات فول الصويا في مصر الصور وديناميكية تعدادها

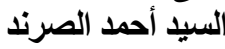 معهز بحوث وقاية النباتات ـ مركز البحوث الزراعية ـالدقي- جيزة ـمصر}

يعثبر بق القطن الدقيقى من الآفات الحشرية الهامة في العالم والتي تسبب ضرراً اقتصاديا لعديد من المحاصيل. ولوحظت هذه الحثة الحشرة

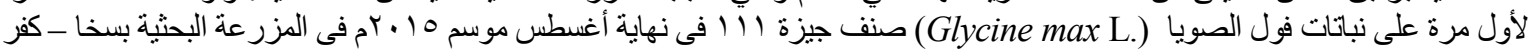

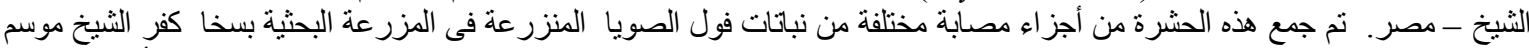

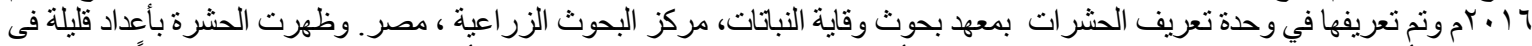

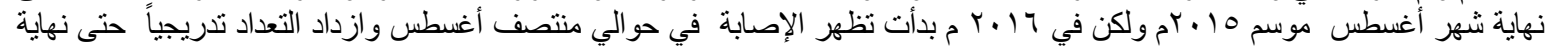

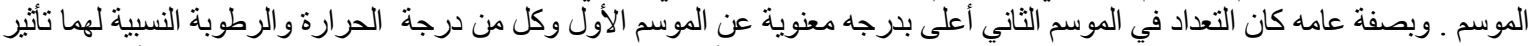

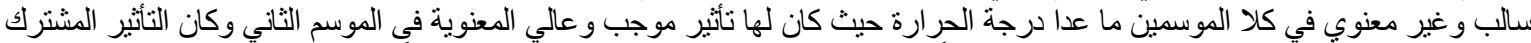

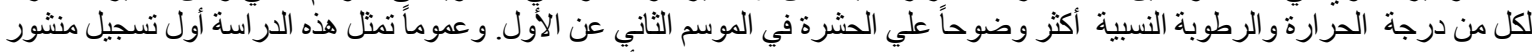

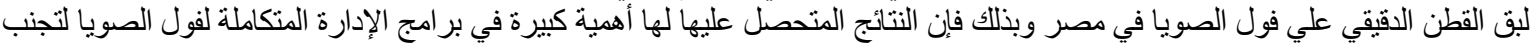
ضرر هذه الحشرة في المستقبل. 